\title{
Effects of local land-use planning on development and disturbance in riparian areas
}

\author{
Judith A. Dempsey, Andrew J. Plantinga, Jeffrey D. Kline, Joshua J. Lawler, \\ Sebastian Martinuzzi, Volker C. Radeloff, and Daniel P. Bigelow
}

$9-6-16$ 


\section{Effects of local land-use planning on development and disturbance in riparian areas}

Abstract: Land-use change can significantly affect the provision of ecosystem services. On a local scale, zoning laws and other land-use regulations are commonly used to influence land-use change, but their effectiveness is often unclear. We evaluate the effectiveness of local land-use planning in concentrating development and minimizing impacts in riparian areas. We use spatially-explicit land cover data from the USGS Land Cover Trends project to measure development and disturbance rates before and after implementation of Oregon's land-use planning system. We apply a difference-in-difference estimator to address the problem of non-random assignment of regulations on the landscape. We find that land-use laws in Oregon have concentrated development inside of UGBs and lowered development rates in riparian areas. However, disturbance in riparian areas has increased inside of UGBs. Overall, our findings suggest that local land-use planning can be an effective tool for promoting the provision of non-market ecosystem services.

Keywords: ecosystem services, land-use planning, difference-in-difference estimator

Acknowledgments: The authors gratefully acknowledge support for this research from the National Science Foundation's Coupled Natural-Human Systems Program and the U.S. Department of Agriculture, Forest Service, Pacific Northwest Research Station. 


\section{Introduction}

Land-use change has large effects on the provision of ecosystem services and biodiversity (Lawler et al. 2014, Millennium Ecosystem Assessment 2005). The conversion of land from less to more intensive uses, such as the transformation of native grasslands into cropland or of forests into development, has greatly increased the production of market goods, including food, fiber, and housing. However, these changes often come at the expense of other ecosystem services, such as air and water quality and open space, and ecosystem functions, such as habitat for wildlife. There are a number of ways that land-use policy can be used to achieve more balance between market and non-market ecosystem services, including implementing market-based incentives to deter harmful private land-use decisions, establishing conservation areas, and using zoning and other land-use regulations to prevent deleterious land-use changes. Of these approaches, zoning and regulatory approaches have the potential to most effectively control land-use decisions, because of the greater control they afford land managers in targeting protection measures to specific locations and for their ability to overcome market forces driving land-use change (Lawler et al. 2014). The provision of important ecosystem services such as carbon sequestration, pollination, pest control, and water purification often depends on how land uses are arranged on a landscape.

At local scales, land-use planning is the primary approach used to influence the spatial pattern of land use. Zoning has been used in the U.S. since the early $20^{\text {th }}$ century to specify permitted uses of land (Mills 1979). In recent decades, urban containment policies, such as urban growth boundaries (UGBs), have become a common tool used to promote compact development (Wassmer 2006). There are many earlier analyses of the effects of land-use regulations on housing and land prices (McMillen and McDonald 2002, Quigley and Rosenthal 2005, Ihlanfeldt 2007, Lynch et al. 2007, Grout et al. 2011), and a smaller number of studies that examine their effects on the rate of land development (recent examples include Cunningham 2007, Boarnet et al. 2011, Dempsey and Plantinga 2013). Several of the studies consider land-use regulations in Oregon, which is our focus 
as well. Knapp (1985) finds that land values are higher within the Portland Metropolitan Area UGB in two of three counties. Grout et al. (2011) find land price differentials of between $\$ 30,000$ and $\$ 140,000$ per acre at the Portland UGB, but also identify sections of the UGB where there is no price change. Dempsey and Plantinga (2013) find higher development rates inside of many of the UGBs in Oregon's Willamette Valley compared to outside, but in some cases find no difference.

The previous literature consider effects of land-use regulations on property values and development rates, but does not analyze the effectiveness of land-use regulations at preventing development of particular types of land, such as forests or riparian areas. Forests sequester carbon and play a major role in climate change mitigation and biodiversity conservation (Dixon et al. 1994), while riparian vegetation protects streams from nonpoint source pollutants and provides habitat for wildlife (Dosskey et al. 2010). Understanding how regulations affect different types of land is important for assessing effects on ecosystem services because of the variation among land uses in the kind and amount of services provided.

Our analysis evaluates zoning and urban growth policies in the U.S. State of Oregon, which is distinctive for its comprehensive and coordinated statewide program. Although Oregon's planning system includes strict land-use controls, such as urban growth boundaries, it is not designed to prevent all development. In this study, we consider the effectiveness of local land-use planning at containing development and limiting development and disturbance in riparian areas. We also present some suggestive evidence on how agricultural and forest lands have been affected under planning rules. Any effort to measure the effects of land-use planning must confront challenges arising from the non-random assignment of zoning and urban growth restrictions to land parcels. In the recent literature, this problem has been addressed with instrumental variables, matching methods, and regression discontinuity design (e.g., Lynch et al. 2007, Grout et al. 2011). In this study, we employ a technique from the program evaluation literature (Imbens and Wooldridge 
2009) called difference-in-difference (DID) estimation. Dempsey and Plantinga (2013) also use a difference-in-difference estimator to study the effects of UGBs on development rates in Oregon. Our study differs from Dempsey and Plantinga (2013) in that we distinguish effects on riparian and non-riparian lands, consider disturbance in addition to development, and evaluate a broader set of land-use regulations.

\section{Background on Oregon's Land-Use Planning Program}

The current land-use planning system in Oregon was created by Senate Bill 100, approved in May 1973, with the goals of protecting farm and forest lands, conserving natural resources, ensuring orderly and efficient land development, facilitating coordination among local governments, and providing for citizen involvement. It directed the Land Conservation and Development Commission (LCDC) to develop planning goals that must be addressed in all local comprehensive land-use plans. The original set of 14 goals was adopted in December 1974. We focused our study on how well cities and counties have addressed Planning Goals 3, 4, 5, and 14. Goal 14 seeks "to provide for an orderly and efficient transition from rural to urban land use" (DLCD 2010). Cities and counties are required to designate UGBs and consider a variety of factors when doing so, such as the need to accommodate projected population increases and satisfy demands for housing and employment. Goal 3 requires that agricultural lands be inventoried and then preserved through the designation of exclusive farm use (EFU) zones. All agricultural lands that are not contained within a UGB, and not specifically designated for nonfarm use, are zoned EFU. Minimum lot sizes are 32 hectares for agricultural land, unless it can be demonstrated that commercial agricultural enterprises can be maintained on smaller parcels. Construction within EFU zones is limited to dwellings and buildings that support agricultural activities. Goal 4 is similar to Goal 3 except that it applies to forests and requires the designation of "forest zones" that are typically 80 acres or greater in size. 
Goal 5 requires local governments to "adopt programs that will protect natural resources and conserve scenic, historic, and open space resources for present and future generations" (DLCD 2010). Particular emphasis is given to riparian corridors. The Administrative Rule for Goal 5 instructs governments to limit permanent alterations to riparian areas, such as the placement of structures or impervious surfaces, and removal of native vegetation. For the most part, locallyadopted Goal 5 ordinances are applied to lands inside of UGBs, one important exception being land zoned for rural residential uses. Riparian management on commercial forest lands outside of UGBs is regulated by the Oregon Forest Practices Act. The Forest Practices Act was passed in 1971, but the rules for riparian management were not developed until the early 1990s, with the final rule adopted in 1994. The rules give landowners flexibility in managing lands in riparian areas, as long as progress is made toward the overarching objective of establishing mature forests. Agricultural lands outside of UGBs are subject to Oregon's Agricultural Water Quality Management Act, which was passed in 1993. This policy requires the development of regional water quality management plans, but does not contain specific rules for riparian management.

Despite the requirements of the land-use planning system, there are a number of ways that development can occur on agricultural and forest lands and in riparian areas. Under Goal 5 rules, local governments can decide not to protect certain natural resources depending on the results of an economic, social, environmental, and energy analysis. Even if forest and riparian areas are protected, exceptions can be granted for roadways and paths, water conveyance, and waterdependent and water-related uses. In these cases, local governments may either grant variances to zoning rules or modify zoning designations in their comprehensive plans. Because land-use planning ultimately is carried out by a large number of local governments, the degree of State oversight is necessarily limited. For all of these reasons, the effectiveness of Oregon's land-use planning system in promoting land conservation has remained an open question (Pease, 1994). 
III. Data

We use USGS Land Cover Trends (LCT) data (Loveland et al. 2002) to estimate land-use changes in areas with and without land-use restrictions. The LCT is a publicly-available, national dataset derived from satellite images, aerial photography, and topographic maps via manual digitizing. The data represent a stratified (by ecoregion) random sample of $100-\mathrm{km}^{2}$ blocks for the years $1973,1980,1986,1992$, and 2000 . Within each block, land cover is mapped at 60-m resolution using the Anderson Level I classification system. More recent LCT observations are also available at 30-m resolution. However, because our analysis included the earliest (1973) observations, we use 60-m data throughout our study period.

We focus our analysis on the Willamette Valley (approximately $30,000 \mathrm{~km}^{2}$ ), which contains Oregon's major cities (Bend and Medford being notable exceptions) and over 70 percent of the State's population. There are thirty-two LCT blocks in the Willamette Valley ecoregion (Figure 1); twenty-nine of these blocks are completely within the Willamette Valley and 3 are partially within the Valley. We use data for 1973 to measure conditions before land-use planning was implemented (i.e., the "before" observations). The enabling legislation for Oregon's land-use planning system was passed in 1973, but actual implementation took place in the years that followed. We use data for 2000 for the "after" observations, which provides us with a sufficiently large window to observe the effects of land-use policies.

The Anderson Level I classification system used for the LCT data consists of eleven landcover categories that are suitable proxies for land-use categories (Anderson et al. 1976). In the first part of our riparian area analysis, we consider whether land in any non-developed category moves to the development category. Developed land is defined as "areas of intensive use with much of the land covered with structures or anthropogenic impervious surfaces ... or less intensive uses where the land cover matrix includes both vegetation and structures ..., including any land functionally 
related to urban or built-up environments." Examples of developed land include high- and lowdensity residential, commercial, and industrial developments, roads, parking lots, cemeteries, and golf courses. Note that clear-cut forest is not classified as development unless and until structures (or other built-up features) are erected.

For the second part of the riparian analysis, we consider whether lands in riparian areas are disturbed. Disturbance is a more comprehensive land cover category, which includes development in addition to agricultural land and land that otherwise has been mechanically disturbed. The mechanically disturbed category is defined as, "land in an altered and often unvegetated state that, due to disturbances by mechanical means, is in transition from one cover type to another." Mechanical disturbances can include earthmoving, scraping, chaining, and reservoir drawdown, but in the Western U.S. it is most often associated with forest clear-cutting (Sleeter et al. 2012). Thus, in the second case, we are concerned with whether land moves from a non-disturbed category to a disturbed category.

Our definition of riparian area is based on existing literature. Castelle et al. (1994) defined a "buffer" as a vegetated zone that is located between natural resources and adjacent areas that are subject to human alteration. There is general consensus about the need for some buffering of aquatic and riparian resources from human influences. However, little agreement exists concerning the size of the buffer that is needed to achieve desired levels of protection. Based on their review of the literature, Castelle et al. (1994) suggested that adequate buffer sizes can vary from 15 to $200 \mathrm{~m}$ depending on the management or conservation goal. For the Pacific Northwest region, it has been suggested that the length of "one mature tree height" is likely adequate for the protection of salmonid species (Young 2000). In old-growth stands in the Pacific Northwest region, mature Douglas-fir trees commonly are 60-75 m tall, and can reach heights of $100 \mathrm{~m}$ or more. Previous studies of riparian areas in Oregon have employed buffer widths that were similar to ours (Burnett 
et al. 2007, Ozawa and Yeakley 2006). However, the width of riparian buffers used in practice is often smaller. For example, the "safe harbor" rules for riparian management in Oregon require buffers from 15 to $22 \mathrm{~m}$.

Reflecting the range of defensible ways to define riparian areas, we consider two alternatives in our analysis - all land within $100 \mathrm{~m}$ or $200 \mathrm{~m}$ of a river or stream. The river and stream data were obtained from the Pacific Northwest Ecosystems Research Consortium (PNERC), which provides a line coverage of the stream network for the Willamette River Basin (Institute for a Sustainable Environment 1999). We include all rivers and streams in the PNERC layer, which includes larger rivers and streams but also smaller, intermittent streams. The river and stream layer did not completely overlap the LCT data for the Willamette Valley, although loss of observations was minimal. An LCT pixel was considered to be within a riparian area if its centroid was within 100 m (or 200 m) of a river or stream. The overlap of the PNERC River Layer and the LCT blocks is shown in Figure 2.

Although our analysis is focused on riparian areas, we examine rates of development for agricultural and forest lands inside and outside of UGBs. Under the Anderson Level I classification system, agricultural land is defined as "land in either a vegetated or an unvegetated state used for the production of food and fiber" and includes cropland, pasture, orchards, vineyards, and confined livestock operations, but not forest plantations. Forests are defined as "tree-covered land where the tree-cover density is greater than $10 \%$."

We also obtained digital maps of UGB locations from the Oregon Department of Land Conservation and Development. We distinguish between riparian areas inside and outside of UGBs because Goal 5 ordinances mostly apply to the former lands, whereas other rules regarding forest practices and water quality apply to the latter. Similarly, rules governing the development of other (non-agricultural, non-forest, or non-riparian) land differ inside and outside of UGBs; for the most 
part, there are fewer development restrictions inside of UGBs. With minor exceptions, agricultural and forest land outside of UGBs is designated EFU and forest zone, whereas agricultural and forest lands within UGBs are not. Finally, because the land-use planning rules apply only to private lands, we obtained data on land ownership from 2008 developed by the Oregon Department of Forestry and available from the Oregon Geospatial Office. We would have preferred to use land-ownership data from an earlier period, but only the 2008 data were available. To our knowledge, public and private ownership has not changed much in this region since the early 1970s, before the date of the earliest land-use data we examined.

Summary statistics for our data set are presented in Table 1. The largest numbers of pixels are in agriculture, forest, and development, respectively. Inside of UGBs, there are more developed pixels than agricultural and forest pixels, but outside of UGBs agricultural and forest pixels are more prevalent. Inside of UGBs, there are a similar number of agricultural, forest, and developed pixels inside riparian areas, but outside of UGBs many more agricultural and forest pixels are found in riparian areas. In absolute terms, the largest change in land use over the 1973 to 2000 period involved forest land outside of UGBs, a decrease of approximately 29,000 pixels. However, this change was mirrored by an increase of almost 21,000 pixels in the mechanically disturbed category, which is associated with clear-cut timber harvesting.

\section{Methods}

The non-random assignment of zoning and urban growth controls is a challenge to accurately measuring the effectiveness of land-use planning. It is not valid to simply compare lands subject to different rules under the planning system, because the experimental "treatments" were not randomly assigned. For example, suppose that one measures how much land is developed within and outside of riparian areas. One might find less development of riparian lands compared to non-riparian lands. However, this does not necessarily indicate that regulations are effective at 
preventing development in riparian areas. It could be that lands outside of riparian areas were already highly developed or that there was development pressure outside but not inside the riparian areas. In other words, lands inside riparian areas may have characteristics that make them less (or more) suitable for development. A simple comparison of riparian and non-riparian areas would mistakenly attribute the effects of these characteristics to regulations, in this case overstating the impact of the policy.

For our application, we measure the effects of land-use planning on conservation outcomes using the DID estimator. The estimator is easiest to explain with a simple illustration of development shares over time for lands inside and outside of riparian areas (Figure 3). The initial year is 1973, before the adoption of Goal 5 ordinances regulating development in riparian areas, and the ending year is 2000 , some years after the policies have been in effect. Suppose that data are available for 1973 and 2000 on the total and developed areas of land inside and outside of riparian areas. For each category and year, one can measure the development share as the ratio of developed to total land area. A comparison of the development shares for 2000 only (labeled "Difference in 2000") is clearly misleading because in 1973, even before the ordinances were adopted, there was a sizable difference in the development shares (labeled "Pre-existing difference"). The DID estimate is computed as the change in the development shares for riparian areas (labeled " $\Delta_{\text {Riparian }}$ ") minus the change in the development share for other lands (labeled $\Delta_{\text {Other }}$ ). Thus, $\Delta_{\text {other }}$ represents the counterfactual change; that is, it is an estimate of how the development share would have increased for riparian areas had the Goal 5 ordinances not been adopted. A comparison of $\Delta_{\text {other }}$ to the actual change ( $\left.\Delta_{\text {Riparian }}\right)$ identifies how much the policy reduced development in riparian areas. By comparison, a matching estimator uses untreated observations with similar characteristics, usually measured at the same point in time, to construct the counterfactual (Rosenbaum and Rubin 1983). 
The error in using "Difference in 2000" to measure the effects of the Goal 5 ordinances is that it includes the "Pre-existing difference" in the development shares as an effect of the policy. However, the Goal 5 ordinances could not have been the cause of the lower development share in riparian areas prior to their adoption. The DID estimator removes the pre-existing difference from the estimate of the policy's effect: $\Delta_{\text {Riparian }}-\Delta_{\text {other }}$ is equal to the "Pre-existing difference" minus the "Difference in 2000". To implement the DID estimator, it is critical that data are available from before and after the adoption of the regulations. If $\Delta_{\text {Riparian }}$ and $\Delta_{\mathrm{O} \text { ther }}$ are measured after the adoption of the regulation, the pre-existing difference between riparian and other lands cannot be identified. It is also necessary that landowners did not anticipate the regulation and undertake preemptive development prior to 1973. If they had, then our estimate of the effects of the regulation could be biased in either direction. The legislative history of the land-use planning system helps to alleviate concerns about pre-emptive development. The official announcement that UGBs would be required was not made until late in 1974 and, even then, no specific information was provided on how the boundaries would be drawn. This was left to the cities and counties to determine. While the key legislation (Senate Bills 10 and 100) passed in 1973, the bills only identified statewide planning goals and neither specifically mentioned UGBs.

The DID estimate accurately measures the effects of the Goal 5 ordinances even if other factors also influenced development between 1973 and 2000. For example, suppose that in addition to the Goal 5 ordinances, an impact fee policy had also been implemented during this period that required developers to reimburse local governments for the additional costs of public services brought about by new development. As long as the impact fees would have affected lands inside riparian areas in the same way as lands outside, the DID estimate would still measure only the effect of the Goal 5 ordinances. To see this, suppose that $\Delta_{\mathrm{Fee}}$ is the reduction in the development share due to impact fees. Then, the observed change in development shares inside riparian areas would have been $\Delta_{\text {Riparian }}-\Delta_{\text {Fee }}$ and the observed change on other lands would have 
been $\Delta_{\text {Other }}-\Delta_{\text {Fee }}$. The DID estimate is unchanged because $\left(\Delta_{\text {Riparian }}-\Delta_{\text {Fee }}\right)-\left(\Delta_{\text {Other }}-\Delta_{\text {Fee }}\right)=\Delta_{\text {Riparian }}-$ $\Delta_{\text {other. }}$ In general, the DID estimate is robust to any influences on development shares during the 1973 to 2000 period, as long as all lands were affected in the same way. This would include influential socioeconomic factors, such as population growth and in-migration of new residents.

We implement the DID estimator using a regression model. The dependent variable is a binary indicator of whether an LCT pixel is developed (or disturbed), which we denote $y_{i t}$ where $i$ indexes pixels and $t$ indexes the year. The regression equation is specified:

$$
\begin{gathered}
y_{i t}=\beta_{0}+\beta_{1} U G B_{i}+\beta_{2} \text { TIME }+\beta_{3} \text { BUFFER }_{i}+\beta_{4} \text { TIME } * U G B_{i}+\beta_{5} \text { TIME } * \text { BUFFER } \\
+\beta_{6} U G B_{i} * \text { BUFFER } R_{i}+\beta_{7} \text { TIME*UGB } * B_{i} * U F F E R_{i}+\epsilon_{i t}
\end{gathered}
$$

where $U G B_{i}$ equals 1 if pixel $i$ is inside of a UGB and 0 otherwise, TIME equals 1 if $t=2000$ and 0 if $t=1973, B U F F E R_{i}$ equals 1 if pixel $i$ is inside of a riparian buffer and 0 otherwise, $\varepsilon_{i t}$ is a random disturbance term, and the $\beta$ s are model coefficients. Because it includes three indicator variables, equation (1) is a difference-in-difference-in-difference (or triple difference) model (Wooldridge 2000). Compared to the difference-in-difference estimator described above, the triple difference model estimates separate effects of regulations inside and outside of UGBs. This allows us to distinguish effects of Goal 5 ordinances from those of the Forest Practices Act and Agricultural Water Quality Management Act.

The coefficients in equation (1) have useful interpretations. The coefficient on the TIME* $U G B$ variable $\left(\beta_{4}\right)$ measures the degree to which planning rules have concentrated development (or disturbance) on non-riparian lands inside of UGBs, accounting for any pre-existing differences in development or disturbance rates. The coefficient on the TIME*BUFFER variable $\left(\beta_{5}\right)$ measures how much the planning rules have raised or lowered development or disturbance rates in riparian areas outside of UGBs. Finally, the coefficient on the triple-interaction variable TIME*UGB* 
BUFFER $\left(\beta_{7}\right)$ measures the degree to which development or disturbance has been affected inside riparian areas that are located inside of UGBs.

We estimate four versions of the model that vary by whether the dependent variable measures development or disturbance and whether we define riparian areas using a $100 \mathrm{~m}$ or $200 \mathrm{~m}$ buffer. For our basic set of results, we pool the observations for all of the cities represented in the data. We also estimate separate models for each UGB area (pixels inside and outside the UGB) in order to characterize potentially heterogenous effects of regulations. This analysis requires that each pixel outside of a UGB be assigned to a UGB, and we assigned pixels to the nearest UGB based on straight-line distances to the closest edge of a UGB. For each UGB area, we report estimates of $\beta_{4}, \beta_{5}$, and $\beta_{7}$ for the development and disturbance models and a $100 \mathrm{~m}$ buffer. The full set of estimates is available from the authors upon request.

\section{Results}

\section{Development and disturbance of riparian lands}

Coefficient estimates and heteroscedasticity-robust standard errors for equation (1) are presented in Table $2 .{ }^{1}$ All coefficient estimates are significantly different from zero at the $1 \%$ level. Model (1) considers effects on development and uses a 100m buffer definition. The coefficient on the TIME *UGB variable is equal to 0.10 , indicating that the development rate for non-riparian lands was 10 percentage points higher inside compared to outside of UGBs. This finding provides evidence that the planning rules concentrated development near existing cities. Nevertheless, some

\footnotetext{
${ }^{1}$ An alternative to heteroscedasticity-robust standard errors are cluster-robust standard errors, which adjust for potential spatial correlation in the residuals. Implementation of this approach requires that we define the clusters, or groups of observations for which we expect residuals to be correlated. One way to cluster is by UGBs, which requires that pixels outside of UGBs be assigned to a UGB. We used the assignment rule based on distance to the nearest UGB edge to define clusters and found that, for the most part, standard error estimates are unaffected.
} 
development occurred outside of UGBs, as indicated by the coefficient on the TIME variable.

Between 1973 and 2000, the amount of non-riparian land developed outside of UGBs increased by 1.2 percentage points. The coefficient on the TIME*BUFFER variable reveals that less

development occurred within riparian areas outside of UGBs, although the effect is relatively small, a -0.5 percentage point reduction. The effects of planning rules in terms of reducing development of riparian lands was larger inside of UGBs. The coefficient on the TIME*UGB*BUFFER variable is -0.028 , indicating that development rates for riparian lands fell by an additional 2.8 percentage points inside of UGBs.

For model (2), the dependent variable is disturbance instead of development. In contrast to the model (1) results, disturbance rates on non-riparian lands were lowered inside of UGBs, as evidenced by the negative coefficient on the TIME*UGB variable. This finding likely reflects the fact that the Forest Practices Act, which applies outside of UGBs, place fewer restrictions on timber harvesting in non-riparian areas. However, these regulations did reduce disturbance in riparian areas. The estimated coefficient on the TIME*BUFFER variable indicates that disturbance rates fell by 2.6 percentage points in riparian areas outside of UGBs. Finally, disturbance rates actually rose in riparian areas inside of UGBs. The estimated coefficient on the TIME*UGB*BUFFER variable reveals that under Goal 5 planning rules disturbance rates for riparian lands were 2.5 percentage points higher inside of UGBs.

Models (3) and (4) use a 200m buffer to define riparian areas instead of a $100 \mathrm{~m}$ buffer. The estimated effects on development and disturbance are mostly unchanged under this alternative definition.

Riparian results by UGB area

In Table 3, we present coefficient estimates for the key variables (TIME*UGB, TIME* $B U F F E R$, and TIME $* U G B * B U F F E R$ ) and for each of the 20 UGB areas. The signs of the 
coefficient estimates mostly correspond to the results in Table 2, although for some of the variables many of the estimates are not significantly different from zero. For the development models, the $T I M E * U G B$ coefficient is positive and significantly different from zero in 16 cases, indicating that development was concentrated on non-riparian lands inside of UGBs. In one case (St. Helens) it is negative and significant and in the remaining cases the estimate is insignificant. Although the sign of the effect is the same as in the pooled model, its magnitude varies from 0.049 in Dundee to 0.437 in Sublimity. This finding suggests that the planning rules are implemented with varying degrees of stringency across municipalities.

The estimated coefficients on the TIME*UGB*BUFFER variable also have the same sign in the development models. Nine of the estimates are negative and significantly different from zero, indicating that regulations applied inside of UGBs had the effect of reducing development rates inside riparian areas. The size of the effect ranges from -0.056 to -0.172 . However, in nine cities no effect was found. ${ }^{2}$ The results for the TIME*BUFFER effect were more varied. Five of the coefficient estimates are negative and significantly different from zero, as in the pooled model, but three estimates are positive and significant and 12 estimates are insignificant. These results indicate widely varying effects of planning rules in terms of influencing development in riparian areas outside of UGBs.

In the disturbance models, the estimated coefficients on the TIME*UGB variables are negative and significant in nine cities and insignificant in the rest. This finding of lower disturbance rates inside of UGBs was also found with the pooled model, although the estimated effects for individual cities are larger (-0.024 to -0.088 compared to -0.005). The TIME*BUFFER coefficient estimates are negative and significant in five cases, positive and significant in one case, and insignificant in the remaining cases. These findings indicate that planning rules in effect outside of

\footnotetext{
${ }^{2}$ For two cities (Donald and Sublimity), the coefficient on the triple interaction term could not be estimated
} because of a lack of data. 
UGBs reduced disturbance in some riparian areas, but for the most part had no effect. Finally, Lowell and Portland Metro appear to be responsible for the positive and significant coefficient on the TIME*UGB*BUFFER variable in the pooled model. The coefficient estimates for these two cities are relatively large ( 0.084 and 0.089 , respectively) and significantly different from zero, whereas the coefficient estimates for the remaining cities are insignificant. As such, we find that planning rules increase disturbance in riparian areas inside of UGBs in two cities, but elsewhere have no effect.

\section{Agricultural and forest lands}

We examine data on agricultural and forest lands to provide some suggestive evidence on how the land-use planning program has differentially affected these types of lands. We are unable to implement a DID estimator in this case because we lack the data to construct a suitable counterfactual. First, we do not observe development rates for agricultural and forest lands in the absence of the planning program. Ideally, we could measure the rate at which these lands were developed before 1973 and use these measures as the development rates that would have occurred had the planning rules never been adopted. Second, it is hard to make an argument that land in non-agricultural (non-forest) uses would have been developed at the same rate as agricultural (forest) lands but for the planning rules. For example, the costs of developing agricultural lands are likely to be lower than the costs of developing non-agricultural lands, such as forests.

As an alternative to formal estimation, we compute development rates for agricultural and forest lands over the 1973 to 2000 period, inside and outside of UGBs (Table 4). Twenty-eight percent of agricultural land inside of UGBs was developed between 1973 and 2000, compared to only $11 \%$ of non-agricultural land. Outside of UGBs more agricultural pixels moved into the development category by 2000 , but rates of development were similar for agricultural and nonagricultural lands. In contrast, development rates were higher for non-forest land inside of UGBs 
than for forest land (25\% compared to 13\%). In large part, the non-forest category is comprised of agricultural land. Outside of UGBs, development rates for forest and non-forest lands were similar. These results show that agricultural lands were developed at a greater rate than forest lands, especially inside of UGBs, during the period when planning rules were adopted in Oregon. Whether the planning rules were the cause of this difference is unclear since there could be other characteristics of agricultural land that make is more economical to develop than forest land, such as flatness and good drainage.

\section{Discussion and Conclusions}

Land-use policies have the potential to deter development in areas that are important for the provision of non-market ecosystem services. However, not all policies are effective (Lewis et al. 2011, Lawler et al. 2014). Our results show that Oregon's land-use planning program has concentrated development inside of UGBs, while at the same time deterring development inside of riparian areas. Development rates were 10 percentage points higher inside UGBs compared to outside and rates were almost 3 percentage points lower inside of riparian areas. The decrease in riparian area development occurred inside of UGBs. Outside of UGBs, the decline was a smaller 0.5 percentage points. We observe that most of the land developed inside the UGB was agricultural land, rather than forest or other lands, although we cannot necessarily attribute this difference to the land-use planning program since agricultural land may be less costly to develop. Outside of UGBs, agricultural and forest land were developed at similar rates.

We also examined disturbance in riparian areas, which includes development as well as conversion to agriculture and mechanical disturbances, which are often associated with timber harvesting. Our results suggest that land-use planning reduced disturbance rates on non-riparian lands inside of UGBs, but increased them inside of riparian areas. Although the changes are not 
large, these findings indicate that planning policies may not always be effective in promoting ecosystem services. Although disturbance rates rose inside of UGBs, outside of UGBs they declined by a similar magnitude.

We estimate separate models by UGB area to explore geographic differences in the effects of land-use planning. Overall, we find that the directional effects on development and disturbance rates are consistent with the results obtained for the pooled model. However, in many UGB areas we find effects that are not significantly different from zero. In the most extreme case, we find large increases in disturbance rates in riparian areas for two UGB areas, but no effect in the other 18 areas. In contrast, the finding that development was concentrated on non-riparian lands inside of UGBs held for almost all of the UGB areas, although there were large differences in the magnitude of the effects. These results may be explained by the fact that municipalities in Oregon have some latitude in how they implement statewide planning goals.

Our results highlight the importance of accounting for the non-random assignment of zoning and other land-use regulations. Inside of UGBs, much greater percentages of non-riparian lands were developed in 2000 compared to riparian lands (63\% compared to 36\%). However, from 1973 to 2000 , there were only small differences in the changes in these percentages (although a large number of non-riparian pixels were developed). The sample proportions for 1973 showed that the large differences between non-riparian and riparian lands existed prior to the implementation of the planning system and other riparian management policies (inside of UGBs, the difference is $52 \%$ compared to $28 \%$ ). The DID estimator removes this pre-existing difference from the estimate of the effects of the policy. This approach requires data prior to the adoption of land-use planning laws. Although time-series information on land use is increasingly common, when these data are unavailable matching and regression discontinuity design (Grout et al. 2011) provide an alternative approach to controlling for non-random assignment of land-use policies. 
Our results have important ramifications for the provision of ecosystem services elsewhere. Currently, there is great interest in increasing the ecosystem services provided on private land (Sanchirico and Siikamaki 2007) and in schemes involving payments for ecosystem services (Jack et al. 2008). A fundamental challenge is to design policies that will be both politically feasible and effective. Private landowners are likely to prefer payments for ecosystem services over traditional regulatory approaches because they receive compensation and can participate on a voluntary basis (Jack et al. 2008). However, voluntary payment schemes may achieve only a small share of the potential gains in ecosystem services, in part because conservation agencies have little control over which lands are conserved (Nelson et al. 2008, Lewis et al. 2011). In theory, regulatory approaches such as zoning give an agency more control over which lands are protected, because they are able to specify permissible uses at particular locations. In practice, however, even regulatory approaches must have some degree of flexibility to strike a balance among competing objectives, and this need for flexibility may reduce overall effectiveness. Our results show that while zoning and other land-use regulations do not completely prevent land development and disturbance, they can prevent land-use changes that would likely have negative impacts on important ecosystem services.

Land use planning evaluations, such as ours, could be used to examine to what extent landuse planning programs aimed to conserve land, such as Oregon's, have resulted in the protection of ecosystem services. The relationships between land protection and ecosystem service provisioning are often non-linear, and where that is the case ecosystem services may still decline even when land protection is successful (Butsic et al., 2010). A number of models based on geospatial interactions provide opportunities for quantifying the ecosystem services provided by different land uses at a variety of spatial scales (Waage et al. 2008). Applications of the spatially explicit InVEST modeling tool, for example, have been used to evaluate changes in the supply and value of ecosystem services resulting from land use change (e.g., Nelson et al. 2010, Polasky et al. 2011, Kovacs et al. 2013). 
Similar applications could augment land use policy analyses such as ours to quantify associated policy effects on ecosystem services. Although such analysis was beyond the scope of our study, our results enable such analyses in the future. Ultimately, we suggest that the most relevant metric of success of any land use planning programs is not just by how much of a given type of land has been protected, but also by the degree to which protected lands provide the ecosystem services that society values and that motivated the land-use planning efforts. 


\section{References}

Anderson, J.R., Hardy, E.E., Roach, J.T., Witmer, R.E. 1976. A Land Use and Land Cover Classification System for Use with Remote Sensor Data. U.S. Geological Survey Professional Paper, 964.

Boarnet, M.G., McLaughlin, R.B., and J.I. Carruthers. 2011. Does State Growth Management Change the Pattern of Urban Growth? Evidence from Florida. Regional Science and Urban Economics 41: 236-252.

Burnett, K., Reeves, G., Miller, D., Clarke, S., Vance-Borland, K., and K. Christiansen. 2007. Distribution of Salmon-Habitat Potential Relative to Landscape Characteristics and Implications for Conservation. Ecological Applications 17(1):66-80.

Butsic, V., Lewis, D.J., and V.C. Radeloff. 2010. Lakeshore Zoning has Heterogeneous Effects on Ecological Indicators as Predicted with Coupled Economic-Biological Models. Ecological Applications 20(3):867-979.

Castelle, A., Johnson, A., and C. Connolly. 1994. Wetland and Stream Buffer Size Requirements - A Review. Journal of Environmental Quality 23:878-882.

Cunningham, C.R. 2007. Growth Controls, Real Options, and Land Development. The Review of Economics and Statistics 89(2): 343-358.

Dempsey, J.A., and A.J. Plantinga. 2013. How Well Do Urban Growth Boundaries Contain Development? Results for Oregon Using a Difference-in-Difference Estimator. Regional Science and Urban Economics 43:996-1007.

Department of Land Conservation and Development (DLCD). 2010. Oregon's Statewide Planning Goals and Guidelines. Department of Land Conservation and Development, Salem, OR. (Available at: http://www.oregon.gov/LCD/docs/goals/compilation of statewide planning goals.pdf).

Dixon, R.K, Solomon, A.M., Brown, S., Houghton, R.A., Trexler, M.C., and J. Wisniewski. 1994. Carbon Pools and Flux of Global Forest Ecosystems. Science (14 Jan.): 185-190.

Dosskey, M. G., Vidon, P., Gurwick, N. P., Allan, C. J., Duval, T. P. and R. Lowrance. 2010. The Role of Riparian Vegetation in Protecting and Improving Chemical Water Quality in Streams. Journal of the American Water Resources Association 46: 261-277.

Grout, C.A., Jaeger, W.K., and A.J. Plantinga. 2011. Land-Use Regulations and Property Values in Portland, Oregon: A Regression Discontinuity Design Approach. Regional Science and Urban Economics 41:98-107.

Ihlanfeldt, K.R. 2007. The Effect of Land Use Regulation on Housing and Land Prices. Journal of Urban Economics 61: 420-435.

Imbens, G.W., and J.M. Wooldridge. 2009. Recent Developments in the Econometrics of Program Evaluation. Journal of Economic Literature 47(1): 5-86. 
Institute for a Sustainable Environment. 1999. River Reach, edition 2. (Available at http://www.fsl.orst.edu/pnwerc/wrb/access.html).

Jack, B.K., Kousky, C., and K.R.E. Sims. 2008. Designing Payments for Ecosystem Services: Lessons from Previous Experience with Incentive-Based Mechanisms. Proceedings of the National Academy of Sciences 105(28):9465-70.

Knapp, G.J. 1985. The Price Effects of Urban Growth Boundaries in Metropolitan Portland, Oregon. Land Economics 61: 26-35.

Kovacs, K., Polasky, S., Nelson, E., Keeler, B.L., Pennington, D., Plantinga, A.J., and Taff, S.J. 2013. Evaluating the Return in Ecosystem Services from Investment in Public Land Acquisitions. PLoS ONE 8(6):1-17.

Lawler, J., Lewis, D., Nelson, E., Plantinga, A.J., Polasky, S., Withey, J., Helmers, D., Martinuzzi, S., and V. Radeloff. 2014. Projected Land-Use Change Impacts on Ecosystem Services in the U.S. Proceedings of the National Academy of Sciences 111(20): 7492-7497.

Lewis, D.J., Plantinga, A.J., Nelson, E., and S. Polasky. 2011. The Efficiency of Voluntary Incentive Policies for Preventing Biodiversity Loss. Resource and Energy Economics 33(1):192-211.

Loveland, T.R., Sohl, T.L., Stehman, S.V., Gallant, A.L., Sayler, K.L., and Napton, D.E. 2002. A Strategy for Estimating the Rates of Recent United States Land Cover Changes. Photogrammetric Engineering and Remote Sensing 68(10): 1091-1099.

Lynch, L., W. Gray, and J. Geoghegan. 2007. Are Farmland Preservation Program Easement Restrictions Capitalized into Farmland Prices? What can Score Matching tell us? Review of Agricultural Economics 29(3): 502-509.

McMillen, D. P., and J. F. McDonald. 2002. Land Values in a Newly Zoned City. The Review of Economics and Statistics 84, no. 1(2002): 62-72.

Millennium Ecosystem Assessment. 2005. Ecosystems and Human Well-being Biodiversity Synthesis. World Resources Institute, Washington, D.C.

Mills, E.S. 1979. Economic Analysis of Urban Land-Use Controls. 1979. In: P. Mieszkowski and M. Straszheim, eds. Current Issues in Urban Economics. Baltimore: Johns Hopkins University Press, pp. 511-541.

Nelson, E., Polasky, S., Lewis, D.J., Plantinga, A.J., Lonsdorf, E., White, D., Bael, D., and J.J. Lawler. 2008. Efficiency of Incentives to Jointly Increase Carbon Sequestration and Species Conservation on a Landscape. Proceedings of the National Academy of Sciences 105(28):9471-6.

Nelson, E., Sander, H., Hawthorne, P., Conte, M., Ennaanay, D., Wolney, S., Manson, S., Polasky, S. 2010. Projecting Global Land-use Change and Its Effect on Ecosystem Service Provision and Biodiversity with Simple Models. PLoS ONE 5(12):1-22. 
Ozawa, C., and J. Yeakley. 2007. Performance of Management Strategies in the Protection of Riparian Vegetation in Three Oregon Cities. Journal of Environmental Planning And Management 50(6):803-822.

Pease J.R. 1994. Oregon Rural Land Use: Policy and Practices. In: Abbot, C., Howe, D., Adler, S. (Eds.), Planning the Oregon Way. Oregon State University Press, Corvallis, OR, pp. 163-188.

Polasky, S., Nelson, E., Pennington, D., and Johnson, K.A. 2011. The Impact of Land-use Change on Ecosystem Services, Biodiversity and Returns to Landowners: A Case Study in the State of Minnesota. Environmental Resource Economics 48:219-242.

Quigley, J.M., and L.A. Rosenthal. 2005. The Effects of Land Use Regulation on the Price of Housing: What Do We Know? What Can We Learn? Cityscape 8(1): 69-137.

Rosenbaum, P.R., and D.B. Rubin. 1983. The Central Role of the Propensity Score in Observational Studies for Causal Effects. Biometrika 7 (1): 41-55.

Sanchirico, J.N., and J. Siikamäki. 2007. Natural Resource Economics and Policy in the 21st Century: Conservation of Ecosystem Services. Resources, Issue 165, Spring.

Sleeter, B.M., Wilson, T.S., and Acevedo, W., eds. 2012. Status and Trends of Land Change in the Western United States-1973 to 2000: U.S. Geological Survey Professional Paper 1794-A, 324 p. (Available at http://pubs.usgs.gov/pp/1794/a/).

Waage, S., Stewart, E., and Armstrong, K. 2008. Measuring Corporate Impact on Ecosystems: A Comprehensive Review of New Tools: Synthesis Report. New York, NY: Business for Social Responsibility.

Wassmer, R.W. 2006. The Influence of Local Urban Containment Policies and Statewide Growth Management on the Size of United States Urban Areas. Journal of Regional Science 46(1): 25-65.

Wooldridge, W.M. 2000. Econometric Analysis of Cross Section and Panel Data. MIT Press.

Young, K. 2000. Riparian Zone Management in the Pacific Northwest: Who's Cutting What? Environmental Management 26(2):131-144. 


\begin{tabular}{|c|c|c|c|c|c|c|c|c|c|c|}
\hline \multirow[b]{3}{*}{ Land-use class } & \multicolumn{10}{|c|}{1973} \\
\hline & \multicolumn{5}{|c|}{ Inside UGB } & \multicolumn{5}{|c|}{ Outside UGB } \\
\hline & $\begin{array}{l}\text { Number } \\
\text { of pixels }\end{array}$ & $\begin{array}{c}\text { Number } \\
\text { in riparian } \\
\text { area } \\
(100 \mathrm{~m})\end{array}$ & $\begin{array}{c}\text { Proportion in } \\
\text { riparian area } \\
(100 \mathrm{~m})\end{array}$ & $\begin{array}{c}\text { Number } \\
\text { in riparian } \\
\text { area } \\
(200 \mathrm{~m})\end{array}$ & $\begin{array}{l}\text { Proportion } \\
\text { in riparian } \\
\text { area }(200 \mathrm{~m}) \\
\end{array}$ & $\begin{array}{l}\text { Number } \\
\text { of pixels }\end{array}$ & $\begin{array}{c}\text { Number } \\
\text { in riparian } \\
\text { area } \\
(100 \mathrm{~m})\end{array}$ & $\begin{array}{l}\text { Proportion } \\
\text { in riparian } \\
\text { area }(100 \mathrm{~m})\end{array}$ & $\begin{array}{c}\text { Number } \\
\text { in riparian } \\
\text { area } \\
(200 \mathrm{~m})\end{array}$ & $\begin{array}{l}\text { Proportion } \\
\text { in riparian } \\
\text { area }(200 \mathrm{~m}) \\
\end{array}$ \\
\hline Water & 1,794 & 837 & 0.47 & 1,256 & 0.70 & 11,003 & 5,155 & 0.47 & 6,864 & 0.62 \\
\hline Developed & 38,404 & 3,035 & 0.08 & 6,989 & 0.18 & 19,890 & 2,918 & 0.15 & 6,547 & 0.33 \\
\hline Mech. disturbed & 58 & 0 & 0.00 & 5 & 0.09 & 6,345 & 496 & 0.08 & 1,054 & 0.17 \\
\hline Mining & 454 & 47 & 0.10 & 107 & 0.24 & 906 & 97 & 0.11 & 202 & 0.22 \\
\hline Barren & 33 & 18 & 0.55 & 22 & 0.67 & 297 & 121 & 0.41 & 157 & 0.53 \\
\hline Forest & 13,088 & 3,179 & 0.24 & 4,909 & 0.38 & 270,187 & 42,303 & 0.16 & 76,041 & 0.28 \\
\hline Grass/shrub & 309 & 25 & 0.08 & 59 & 0.19 & 5,936 & 672 & 0.11 & 1,389 & 0.23 \\
\hline Agriculture & 22,852 & 3,056 & 0.13 & 6,539 & 0.29 & 365,104 & 51,707 & 0.14 & 108,894 & 0.30 \\
\hline Wetland & 1,388 & 580 & 0.42 & 865 & 0.62 & 10,518 & 4,850 & 0.46 & 7,342 & 0.70 \\
\hline \multirow[t]{3}{*}{ Total } & 78,380 & 10,777 & 0.14 & 20,751 & 0.26 & 690,186 & 108,319 & 0.16 & 208,490 & 0.30 \\
\hline & \multicolumn{10}{|c|}{2000} \\
\hline & \multicolumn{5}{|c|}{ Inside UGB } & \multicolumn{5}{|c|}{ Outside UGB } \\
\hline Land-use class & $\begin{array}{l}\text { Number } \\
\text { of pixels }\end{array}$ & $\begin{array}{c}\text { Number } \\
\text { in riparian } \\
\text { area } \\
(100 \mathrm{~m})\end{array}$ & $\begin{array}{c}\text { Proportion in } \\
\text { riparian area } \\
(100 \mathrm{~m})\end{array}$ & $\begin{array}{c}\text { Number } \\
\text { in riparian } \\
\text { area } \\
(200 \mathrm{~m})\end{array}$ & $\begin{array}{l}\text { Proportion } \\
\text { in riparian } \\
\text { area }(200 \mathrm{~m}) \\
\end{array}$ & $\begin{array}{l}\text { Number } \\
\text { of pixels }\end{array}$ & $\begin{array}{c}\text { Number } \\
\text { in riparian } \\
\text { area } \\
(100 \mathrm{~m})\end{array}$ & $\begin{array}{l}\text { Proportion } \\
\text { in riparian } \\
\text { area }(100 \mathrm{~m})\end{array}$ & $\begin{array}{c}\text { Number } \\
\text { in riparian } \\
\text { area } \\
(200 \mathrm{~m})\end{array}$ & $\begin{array}{l}\text { Proportion } \\
\text { in riparian } \\
\text { area }(200 \mathrm{~m}) \\
\end{array}$ \\
\hline Water & 1,698 & 805 & 0.47 & 1,208 & 0.71 & 11,787 & 5,387 & 0.46 & 7,281 & 0.62 \\
\hline Developed & 46,780 & 3,883 & 0.08 & 8,896 & 0.19 & 27,097 & 3,638 & 0.13 & 8,433 & 0.31 \\
\hline Mech. disturbed & 556 & 86 & 0.15 & 191 & 0.34 & 27,080 & 1,747 & 0.06 & 4,516 & 0.17 \\
\hline Mining & 409 & 48 & 0.12 & 103 & 0.25 & 1,182 & 117 & 0.10 & 262 & 0.22 \\
\hline Barren & 41 & 25 & 0.61 & 30 & 0.73 & 346 & 138 & 0.40 & 207 & 0.60 \\
\hline Forest & 11,310 & 2,914 & 0.26 & 4,375 & 0.39 & 241,171 & 40,409 & 0.17 & 71,020 & 0.29 \\
\hline Grass/shrub & 341 & 36 & 0.11 & 80 & 0.23 & 9,407 & 729 & 0.08 & 1,619 & 0.17 \\
\hline Agriculture & 15,893 & 2,379 & 0.15 & 4,975 & 0.31 & 361,999 & 51,329 & 0.14 & 108,004 & 0.30 \\
\hline Wetland & 1,352 & 601 & 0.44 & 893 & $55^{0.66}$ & 10,117 & 4,825 & 0.48 & 7,148 & 0.71 \\
\hline Total & 78,380 & 10,777 & 0.14 & 20,751 & 0.26 & 690,186 & 108,319 & 0.16 & 208,490 & 0.30 \\
\hline
\end{tabular}




\begin{tabular}{|l|c|c|c|c|}
\hline \multicolumn{5}{|c|}{ Table 2: Development and Disturbance Results for Pooled Model } \\
\hline & $100 m$ buffer & $100 \mathrm{~m}$ buffer & $200 \mathrm{~m}$ buffer & $200 \mathrm{~m}$ buffer \\
\hline & development & disturbance & development & disturbance \\
\hline Variable & $(1)$ & $(2)$ & $(3)$ & $(4)$ \\
\hline UGB & 0.492 & 0.215 & 0.516 & 0.233 \\
\hline Time & $(0.002)^{* * *}$ & $(0.002)^{* * *}$ & $(0.002)^{* * *}$ & $(0.002)^{* * *}$ \\
\hline Buffer & 0.012 & 0.044 & 0.012 & 0.047 \\
\hline Time*UGB & $(<0.001)^{* * *}$ & $(0.001)^{* * *}$ & $(0.000)^{* * *}$ & $(0.001)^{* * *}$ \\
\hline & -0.003 & -0.077 & 0.003 & -0.019 \\
\hline Time*Buffer & $(0.001)^{* * *}$ & $(0.002)^{* * *}$ & $(0.000)^{* * *}$ & $(0.001)^{* * *}$ \\
\hline & 0.100 & -0.019 & 0.101 & -0.023 \\
\hline UGB*Buffer & $(0.003)^{* * *}$ & $(0.002)^{* * *}$ & $(0.003)^{* * *}$ & $(0.002)^{* * *}$ \\
\hline & -0.005 & -0.026 & -0.002 & -0.023 \\
\hline Time*UGB*Buffer & $(0.001)^{* * *}$ & $(0.002)^{* * *}$ & $(0.001)^{* * *}$ & $(0.002)^{* * *}$ \\
\hline & -0.239 & -0.175 & -0.212 & -0.158 \\
\hline Constant & $(0.005)^{* * *}$ & $(0.005)^{* * *}$ & $(0.004)^{* * *}$ & $(0.004)^{* * *}$ \\
\hline Notes: Heteroskedasticity-robust standard errors in parentheses. Three & $(0.007)^{* * *}$ & $(0.007)^{* * *}$ & $(0.006)^{* * *}$ & $(0.005)^{* * *}$ \\
\hline asterisks denote significance at the $1 \%$ confidence level. & -0.019 & 0.024 \\
\hline
\end{tabular}




\begin{tabular}{|c|c|c|c|c|c|c|}
\hline \multicolumn{7}{|c|}{ Table 3: UGB-specific Development and Disturbance Results for a 100m Riparian Buffer } \\
\hline & \multicolumn{3}{|c|}{ Development } & \multicolumn{3}{|c|}{ Disturbance } \\
\hline & Time*UGB & Time*Buffer & Time*UGB*Buffer & Time*UGB & Time*Buffer & Time*UGB*Buffer \\
\hline UGB & $(1)$ & $(2)$ & (3) & (4) & $(5)$ & (6) \\
\hline Brownsville & -0.004 & $0.005^{* *}$ & -0.005 & $-0.084^{* * *}$ & $-0.038 * * *$ & 0.038 \\
\hline Carlton & 0.008 & $0.010 * *$ & 0.016 & 0.006 & 0.005 & -0.005 \\
\hline Corvallis & $0.092^{* * *}$ & -0.003 & -0.047 & $-0.025^{* * *}$ & $-0.018^{*}$ & 0.010 \\
\hline Dallas & $0.063 * * *$ & 0.002 & -0.012 & $-0.087^{* * *}$ & $-0.028 * * *$ & 0.018 \\
\hline Dayton & $0.090^{* * *}$ & $-0.005^{* * *}$ & $-0.079 * *$ & 0.001 & 0.003 & 0.004 \\
\hline Donald & $0.252^{* * *}$ & -0.005 & & 0.015 & -0.001 & \\
\hline Dundee & $0.049 * *$ & -0.006 & $-0.066 * *$ & $-0.024 * *$ & -0.023 & 0.023 \\
\hline Estacada & -0.018 & $-0.015^{* * *}$ & 0.015 & -0.020 & -0.011 & 0.013 \\
\hline Harrisburg & $0.100 * * *$ & -0.002 & -0.014 & 0.002 & -0.001 & 0.058 \\
\hline Lafayette & $0.185^{* * *}$ & 0.001 & $-0.172 * * *$ & 0.006 & -0.010 & -0.001 \\
\hline Lebanon & $0.066 * * *$ & $0.003 * * *$ & 0.034 & -0.008 & $0.014^{* *}$ & -0.014 \\
\hline Lowell & $0.136^{* * *}$ & -0.001 & $-0.137 * * *$ & $-0.088^{* * *}$ & $-0.086 * * *$ & $0.084^{* * *}$ \\
\hline Portland Metro & $0.058^{* * *}$ & $-0.035^{* * *}$ & $0.039 * * *$ & $-0.066 * * *$ & $-0.065 * * *$ & $0.089 * * *$ \\
\hline McMinnville & $0.184^{* * *}$ & -0.001 & $-0.163^{* * *}$ & 0.005 & 0.005 & 0.003 \\
\hline Newberg & $0.065^{* * *}$ & $-0.023 * * *$ & $-0.072^{* *}$ & $-0.024^{* * *}$ & -0.006 & 0.001 \\
\hline Philomath & $0.121^{* * *}$ & -0.005 & $-0.056^{*}$ & $-0.033 * * *$ & -0.019 & -0.030 \\
\hline Sheridan & $0.278 * * *$ & -0.001 & $-0.137 * *$ & $-0.024^{* * *}$ & -0.016 & 0.016 \\
\hline St. Helens & $-0.050 * *$ & $-0.071 * * *$ & 0.051 & 0.007 & -0.003 & -0.004 \\
\hline Stayton & $0.093^{* * *}$ & -0.003 & $-0.062 * *$ & 0.004 & -0.004 & -0.009 \\
\hline Sublimity & $0.437 * * *$ & -0.002 & & $<0.001$ & -0.000 & \\
\hline \multicolumn{7}{|c|}{$\begin{array}{l}\text { Notes: The asterisks, } * * *, * * \text {, and } * \text {, denote significance at the } 1 \%, 5 \% \text {, and } 10 \% \text { significance levels, respectively. A table entry of } \\
>-0.001 \text { indicates a negative estimate contained in the }(-0.001,0) \text { interval. A table entry of }<0.001 \text { indicates a positive estimate } \\
\text { contained in the }(0,0.001) \text { interval. }\end{array}$} \\
\hline
\end{tabular}




\begin{tabular}{|c|c|c|c|c|c|c|}
\hline \multirow[b]{3}{*}{ Category } & \multirow{2}{*}{\multicolumn{3}{|c|}{ Sample Proportions (Development) }} & \multirow{2}{*}{\multicolumn{2}{|c|}{ Number of Developed Pixels }} & \multirow{3}{*}{ Total Pixels } \\
\hline & & & & & & \\
\hline & 1973 & 2000 & Difference & 1973 & 2000 & \\
\hline Agricultural land, inside UGB & 0.00 & 0.28 & 0.28 & 0 & 6,484 & 22,843 \\
\hline Non-agricultural land, inside UGB & 0.00 & 0.11 & 0.11 & 0 & 1,884 & 17,020 \\
\hline Difference & & & 0.17 & & & \\
\hline Agricultural land, outside UGB & 0.00 & 0.02 & 0.02 & 0 & 5,741 & 359,701 \\
\hline Non-agricultural land, outside UGB & 0.00 & 0.01 & 0.01 & 0 & 1,377 & 270,385 \\
\hline Difference & & & 0.01 & & & \\
\hline Forest land, inside UGB & 0.00 & 0.13 & 0.13 & 0 & 1,676 & 12,988 \\
\hline Non-forest land, inside UGB & 0.00 & 0.25 & 0.25 & 0 & 6,692 & 26,875 \\
\hline Difference & & & -0.12 & & & \\
\hline Forest land, outside UGB & 0.00 & 0.01 & 0.01 & 0 & 1,271 & 243,646 \\
\hline Non-forest land, outside UGB & 0.00 & 0.02 & 0.02 & 0 & 5,847 & 386,440 \\
\hline Difference & & & -0.01 & & & \\
\hline
\end{tabular}


Figures

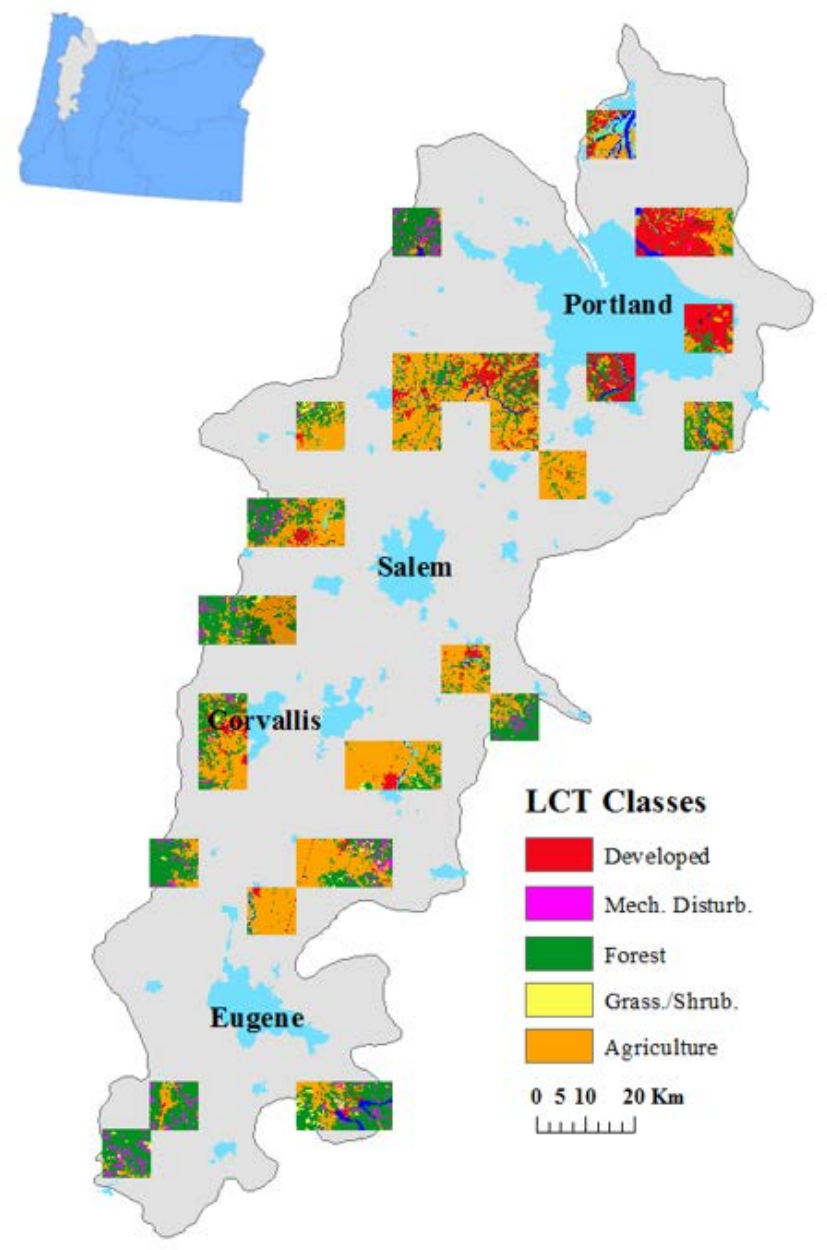

Figure 1. LCT Blocks in the Willamette Valley Ecoregion. Areas inside of urban growth boundaries are indicated in light blue. 


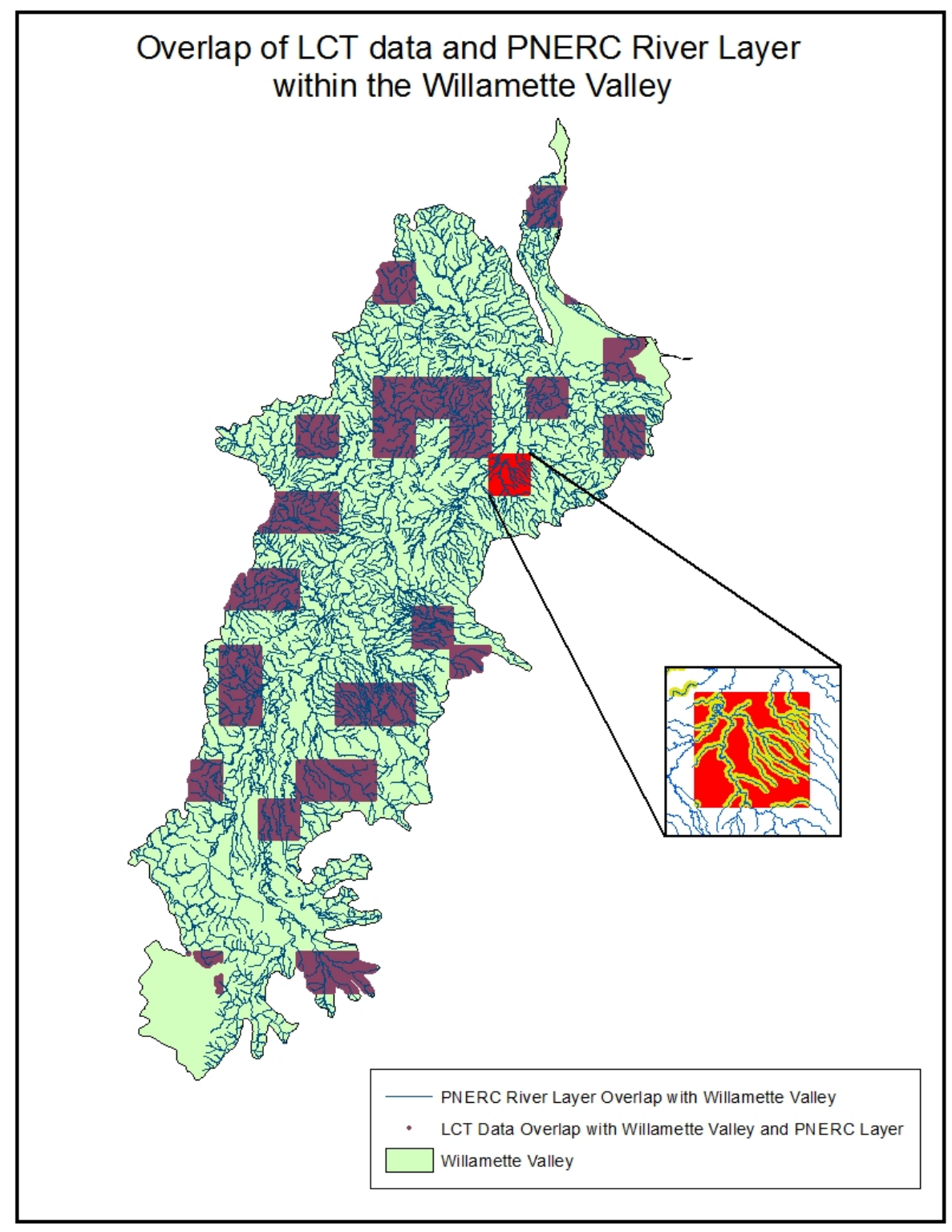

Figure 2. Overlap of LCT blocks and PNERC River Layer in the Willamette Valley Ecoregion. LCT blocks shown in purple, rivers in blue. The red block is enlarged to show the river layer with the 100 meter buffer. 
Percentage of Land

In Development

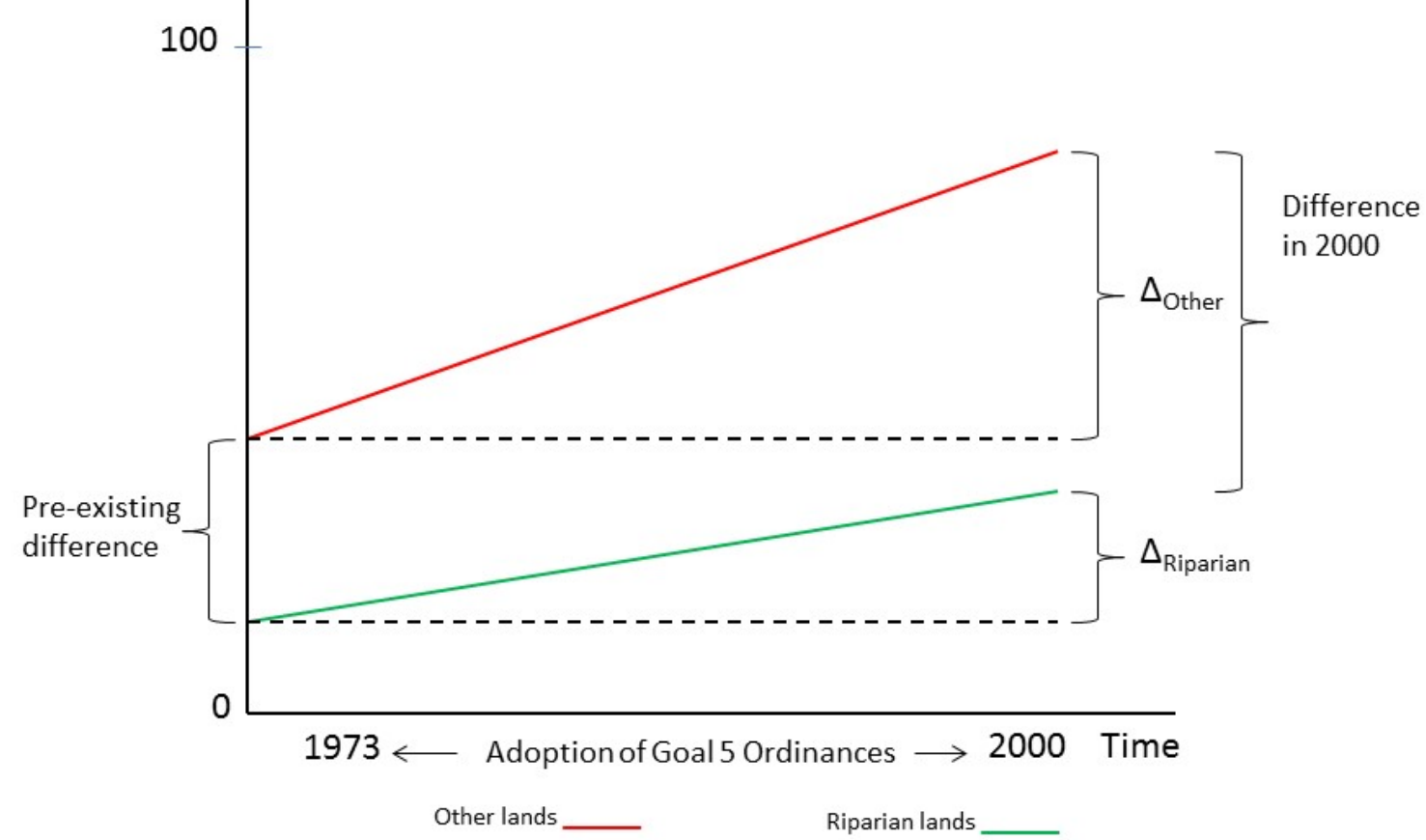

Figure 3. Illustration of the difference-in-difference estimator. The green and red lines show how the share of land in development changed inside and outside of riparian areas, respectively. In 2000, there is a large difference in the development share for riparian areas and other lands (Difference in 2000). Much of this difference is due to differences in the shares that existed before 1973 , prior to the adoption of the Goal 5 ordinances. The difference-in-difference estimate $\left(\Delta_{\text {Riparian }}{ }^{-} \Delta_{\text {Other }}\right)$ removes the effects of pre-existing differences in development shares to give a more accurate estimate of the effects of Goal 5. 